\title{
EVOLUTION OF THE COASTAL ZONE MANAGEMENT LAW IN INDIA AND ITS IMPLEMENTATION: CASE STUDY OF MUMBAI METROPOLITAN REGION, INDIA
}

\author{
GURKEERAT SINGH GILL \& KIRAN SHINDE \\ GRV Realinfra Consultants Pvt. Ltd, India
}

\begin{abstract}
The Union of India adopted a comprehensive Environment (Protection) Act in 1986, pursuant to the decision taken at the United Nations Conference on Human Environment held at Stockholm in 1972. However, it was not until 1991 that the first notification of the Government was issued clearly laying down the mitigation measures for extensive depletion of the coastal environment by human activities. This notification also provided elaborate procedures to regulate development of coastal areas. Notification has been amended many times - the last being in January 2019. The notifications from 1991 have majorly affected the high value properties in the coastal cities all along the 7,516 km of the country's coastal stretch. This pinching of the property rights has created multiple pressure points and contrasting vested interests of the property owners, the local governments and the environment activists. Stakeholders have impacted the status of the coastal zones - in its flora, fauna, geographical extensions, social and economic potential and its exploitation. The response has been changes in law, judicial activism, and environmental litigation. Integration of the Coastal Zone Management Plans with the local laws is a major challenge. The Constitution of India provides for both exclusive and shared jurisdiction for the Union, State and Local Governments. This triad of jurisdictions has kept integrated management of the coastal zone at bay - at least at this time. The Mumbai Metropolitan Region is financially the most important region in India. The land value closer to the coast are high and the citizens have high awareness of this unique value. The same level of awareness amongst the non-property owners gives rise to intense slugfest between the stakeholders. This provides a perfect testing ground for success of the CZMPs. This paper critically analyses the evolution of law, its implementation and progressive adaptation. The Pressure-Status-Response (PSR) model will be used to analyse the impact of the law on human environment.
\end{abstract}

Keywords: Mumbai, Bombay, CRZ, environment, mangroves, urbanization, coastal zone law.

\section{INTRODUCTION}

1986 was a watershed year for Environmental Law in India. Omnibus Environment Protection Act (EPA) was duly enacted in this year by the Indian Parliament. Admittedly the main inspiration for this enactment, amongst others was "decisions taken at the United Nations Conference on the Human Environment" held at Stockholm in 1972. This Conference as in many other countries also, initiated a process of awareness amongst the Indian Polity and forced them to re-examine the developmental priorities in their impact upon environmental resources of all types. Between 1972 and 1986, this awareness took a firm footing and manifested itself in this historic enactment. Not to deny that India always had sector specific (Clean Water Act, Clean Air Act, etc.) legislation, but this Act had significance because:

a. It is general legislation on environment protection giving vast powers to curtail private rights particularly rights to property.

b. It seeks to co-ordinate activities of various regulatory agencies - both State and Federal. 
c. It seeks to create authorities with advocacy powers for environmental protection. This is very important to legitimate the supremacy of environment over development.

The legitimacy of direct and strong application of the Act, to the coastal ecosystems is drawn from the very definition of the environment in the Act.

"Environment includes water, air and land and the interrelationships which exist among and between water, air and land and human beings, other living creatures, plants, micro-organisms and property" [1].

Exercising powers under this general and potent law, the Government of India started a series of actions by way of official notifications putting severe restrictions on the development of property in coastal areas thus depriving the owners of such properties to reap fruits thereof.

\section{OBJECTIVE AND METHODOLOGY}

Coastal areas are demographic concentrations and have always been associated with highend living. This has led to high prices of the properties along the coast. The climate change scenario has now thrown a challenge for protection of the coastal areas and retention of the property values. Various alternatives of tackling this like development restrictions, tenure restrictions, and sustainable solutions are available depending on the interplay of the PSR elements of the model [2]. The conflicting interests has led to passing of legislation that is too ambitious and restrictive to begin with but is progressively modified to accommodate other interests. Objective of this study is to clearly discern the interests and their conflicting nature. This analysis will help balanced future policy decisions - hopefully.

First stage was obviously to analyze various pieces of legislation, judgements, research papers bearing upon the overall Indian State concern for environmental issues, with reference to the coastal management issues. These documents were related to the three periods: pre 1991; between 1991 and 2011; and between 2011 and 2019. Interim period between the milestone legislation was the period of play of the PSR Model. These PSR elements were studied to see if they are pro-development, pro-environment or neutral. Their impact was finally analyzed through objective parameters of changes in Floor Space Index, extension and/or contraction of the coastal regulation zone and changes in the definition of sub zones and inclusion or exclusion of the activities with in the coastal management zone.

\section{COASTAL AREA MANAGEMENT LAW IN INDIA 1991-2011}

After the enactment of the omnibus legislation as described in above para a clear momentum in the sphere of management of coastal areas is inferred. In the initial phases it was knee jerk reaction based on observation of some political person - in India's case the late Prime Minister Mrs Indra Gandhi is credited (or discredited) for making a wide and impromptu declaration on visit to the coastal State of Goa to ban all activity in the vicinity of beaches and to keep beaches clean. Post this statement however the formal law has been made with much more attention to the nuances of environment and human interplay. Fig. 1 depicts various pieces of subordinate legislation enacted since 1981. Various Pressures had evoked these Responses, thus altering the concept, intent and extent of Coastal Zone Management [3]. 
1981: Directive by the then Prime Minister of India to keep beaches clean and free of development

1987: Beach guidelines issued by the then Department of Environment

1989-1990: Draft Coastal Regulation Zone notification issued. This was revised in 1990

$19^{\text {th }}$ February 1991: Final Coastal Zone Management Notification issued by the Govt. of India

July 2004: Constitution of the Prof. M S Swaminathan Committee to suggest integration of the various pieces of legislation and subordinate legislation concerning coastal areas.

2008: Draft Coastal Zone Management Notification issued but later withdrawn on multiple suggestions and objections.

July 2009: Prof. M S Swaminathan Committee reconstituted to consider all Coastal issues and suggest policy and legal framework.

1992-2011: 25 amendments are notified to the 1991 basic notification. These were all related to the individual cases.

2010-2014: This was an era of creation of multiple entities as follows:

2010: Integrated Coastal Zone Management Project (ICZM) with World Bank Assistance

2011: Constituted Society for ICZM (SICOM)

2013: Established National Centre for Sustainable Coastal Management under the aegis of SICOM

14 Institutions incorporated in consortium to create a Knowledge Source Hub

June 2014: Dr. Shailesh Naik Committee (SNC) to review and suggest actions on the representation from various States on the provisions of 2011 Notification

Jan 2015: SNC Report recommended issuing of new Notification.

March 2015-April 2016: 8 amendments issued by MOEFCC based on the essence and logic of SNC Report. Only 4 were issued following prescribed procedure.

January 2019: New Notification issued superseding the Notification of 2011

Figure 1: Subordinate legislation enacted since 1981.

\section{EVOLUTION OF LAW DURING THIS PERIOD}

\subsection{Driving forces for legislation}

Though the journey of Coastal Zone Management Law in the country started with a single directive of the Prime Minister, it has amassed a copious content through various legislative actions and judicial pronouncements. Legislative Action is the Response of the Government/s at all three levels of the government in India. Pressure points for the Government/s to act are:

1. Environmental Activism - through media, judicial process, seminars and conferences.

2. Pressure due to International Declarations and Conventions, etc. 
3. Need for creation of physical infrastructure - such as ports and allied activities, airports, roads and bridges.

4. Increasing urbanization enhancing need for affordable housing, sanitation, infrastructure.

5. Judicial directives in the Public Interest Litigation.

6. Public Trust Doctrine.

7. Precautionary Principle.

8. Private interest - particularly of the property owners adversely impacted due to restrictions on use.

\subsection{Judicial overreach}

Judicial pronouncements almost fully arising out of the Public Interest Litigation initiated by the Environmental Activists have quite often not limited itself to "interpretation of the law". It has not hesitated to declare law as ultra-vires of the Constitution by invoking the Public Trust Doctrine and the Precautionary Principle. Judiciary has many times also ventured into setting up the Administrative Machinery to oversee the implementation of its directives.

\section{CONSTITUTION OF INDIA AND JUDICIAL INTERVENTION}

\subsection{Constitutional provisions}

Directive Principles of the State Policy, though not binding nonetheless obligate the State to steer its long-term objectives to serve the intent of these Principles. Article 48 A in Chapter IV reads as follows:

"48A - Protection and improvement of Environment and safeguarding of forests and wildlife: The State shall endeavor to protect and improve the environment and to safeguard the forests and wildlife of the country."

Besides the Directive Principles, the Chapter on Fundamental Duties of the Citizens also lays down following provisions:

"51A - Fundamental Duties: It shall be the duty of every citizen of India:

(g) to protect and improve the natural environment including forests, lakes, rivers, wildlife and to have compassion for living creatures."

Within the umbrella of above said Directive Principles and the Fundamental Duties, and the India's signature to the International Conventions particularly The Rio Declaration on environment and development (1992), the Environmental Activism and Judicial Intervention has been prolific even at the cost of violation of the Constitutional Fundamental Right of "Right to Property". This supremacy of the Directive Principles over the Fundamental Rights is justified on the Public Trust Doctrine and the Precautionary Principal [4]. 


\section{PUBLIC TRUST DOCTRINE AND PRECAUTIONARY PRINCIPAL}

Public Trust Doctrine can be traced back to the Roman Times and has evolved in various national, religious and cultural systems in unison with the specific history and economics thereof. Original Roman principles were based on premise of abundance, which need much change now. Two major categories of resources to which these can be extended are: commonly available such as air, water, sea and sea shores - the last now being progressively privately held; secondly those resources which were common but have been partly acquired by private citizens - most significant of these being the land which includes the sea shore and also the coastal properties.

The Supreme Court of India in a much-reported judgement has held the public trust doctrine is a tool for exerting long established public rights over short term public rights and private gain. It further clarified that landowner or lessee, or a water right holder has an obligation to use such resources in a manner as not to impair or diminish the people's rights and the people's long-term interests in that property or resource. This is a very wide application of the doctrine overtaking the fundamental right to property [5].

Rio Declaration on Environment and Development clearly defined Precautionary Principal as "Where there are threats of serious or irreversible damage, lack of full scientific certainly shall not be used as a reason for postponing cost-effective measures to prevent environmental degradation". Legislative and Judicial Wings of the Government of India have taken serious and sincere view of the Principle as is reflected in various enactments, government notifications and the copious judicial intervention. Apex Court of the Country has held in one of the matters before it "The 'Precautionary Principle' has been accepted as a part of the law of land ... The Precautionary Principle makes it mandatory for the State Government to anticipate, prevent and attack the causes of environment degradation". With so much support and action forcing decisions Response of the State Actors has been adequate at least in formulation of public policies [6], [7].

\section{ANALYSIS OF EVOLUTION OF LAW}

\subsection{Through PSR Model}

The PSR Model was first used by Tony Friend and David Rapport in 1979. It has gone through multiple iterations and adaptations since then. The Model is flexible and amenable to application in various complex system studies. PSR is particularly useful for understanding the "action-response" dualism in sustainable development. Three components - Environmental Pressures, the State of the Environment and the Environmental Response and their interactions form the backbone of this Model in its applicability to the environmental systems. OECD has continuously used this Model since 1970s in its work on environmental reporting. The classic PSR Model in its application to understand the environment-human interactions, identifies environmental pressures from human activities on the environment including the natural resources. These Pressures may be of two types: firstly "underlying" or "indirect". For example, any activity impacting environment will be an indirect pressure and secondly there are more "direct pressures" such as use of natural resources or destruction thereof by fire, floods, human greed etc. Non-direct pressures are a by-product of socio-economic milieu and political leadership. We will revert to this again while considering PSR application to the subject of this paperMMR Region [8].

State component in the classic PSR Model is the "State of Environment" which shall include quality and quantity of natural resources and its degradation or otherwise over a 
period. Clear understanding of the State is the trigger point for "Response" which may be in form of policy decisions, or direct action. Another dimension of the "State" is its extension in time and space. Understanding of "State" in this dimension is key to discerning trends of progressive status of any eco-system.

"Response" in the environmental context can vary from individual to collective, societal to governmental, local to regional to national and to global. It can be economic, legislative, judicial or a combination of them depending on the social system or the organ of social system that is driving the "response".

\subsection{Other framework and models}

There are at least two other prominent frameworks, that facilitate the understanding and analysis of the complex environmental systems. For example, Environmental Accounting is based on the "physical input-output" tables tracing the production, transformation and the use of each resource throughout the economy. Comparing the results from the different economies can help to establish the "natural resource use efficiency" of each economy. Other agencies like World Bank, European Environment Agency use PSR Model with additional information or also altogether different Models. United Nations Development Program (UNDP) has created its own "Composite Indicators" like Human Development Index (HDI). HDI contains indicators of health, education, economics, and social welfare etc. EEA uses DPSIR Framework - Driving Force-Pressure-State-Impact-Response. Even though the terminology like Pressure, State and Response is same the intent and focus can vary substantially. Pressure here is a direct consequence of the Driver's Needs. For example, the need to protect private property rights in local areas may result in "sociopolitical" pressure which will impact the physical, chemical and biological State of the coastal eco-systems. Responses here in addition to the ones identified in the earlier section will also include identification, prioritisation, target setting, funding, and monitoring [9].

Comparing two models it will be seem that the DPSIR Framework is an unbundling of some of the conceptual thoughts in PSR Model as follows:

1. Drivers and Pressures included in Pressure in PSR.

2. State and Impact included in State. Determination of State is the result of study and evaluation of the Impact.

3. Response is included in both the Frameworks, DSPIR Framework has given it a meta dimension to the Response as envisaged under the PSR Framework.

\section{MUMBAI METROPOLITAN REGION}

Mumbai Metropolitan Region (MMR) extends over an area of $4,234 \mathrm{~km}^{2}$. It is holding a population of 12.4 million, out of which about $55 \%$ resides in the core city of Mumbai. MMR has a coastal length of $256 \mathrm{~km}$. This coastal stretch besides supporting directly the livelihoods of some 160,000 fishermen, also supports large scale salt manufacturing activity. These salt pans cater up to $98 \%$ of the requirement of the entire state of Maharashtra. Other coastal ecosystem-human interaction is [10]:

1. Debris dumping in the coastal stretches with aim to reclaim (grab) the land for construction activities.

2. Residential and industrial waste disposal - mostly untreated.

3. Mobility related impacts like new roads, bridges, railway lines, airport.

4. Coastal marine pollution [11]. 
The entire coastline is also home to two major ports - Mumbai Port and Jawaharlal Nehru Port. Together these two ports handled nearly 130 million tonnes of cargo which is over $17 \%$ of the country's total tonnage handled. Besides these major ports there are over 31 jetties comprised into 12 port groups for administrative purpose. Thus, the coastline of the MMR besides being sea front to the valuable land is also the host to country's main trade routes [12]. From the physical geography point of view the entire coastline of $128 \mathrm{~km}$ of core city of Mumbai in the MMR can considered to represent following features: Rocky Outcrops - 17 locations; Beaches - 15 locations; Mangroves - seven locations; Coastal land development - six locations. Rest of the MMR has one beach location and seven major creeks [13]. Main problems in the MMR Coastal region can be related to land use pattern, residential and industrial water supply and waste disposal, transportation related air, soil and noise pollution, coastal marine pollution, depletion of important coastal habitats like wetlands and mangroves [14].

\section{PRESSURE STATE RESPONSE: MMR ANALYSIS}

We will discuss "Pressures" in terms of the environment/resources impacted. The impact quantification on the "State" of the environment and the type of "Response" (legislative, judicial, social activism) will be discussed. Fig. 2 explains this dynamism and two-way action in terms of the PSR Model.

\begin{tabular}{|c|c|c|c|c|}
\hline PRESSURE & & & RE & SE \\
\hline $\begin{array}{l}\text { INDIRECT PRESSURES } \\
\text { Urbanisation } \\
\text {-Housing } \\
\text {-Solid waste } \\
\text {-Infrastructure } \\
\text { Human Greed } \\
\text {-Land reclamation } \\
\text { (grabbing) } \\
\text {-Profit maximisation } \\
\text {-Overuse of natural } \\
\text { resources } \\
\text { Public Sector } \\
\text {-Infrastructure } \\
\text {-Inappropriate } \\
\text { policies }\end{array}$ & $\begin{array}{l}\text { Pollution, } \\
\text { Encroach } \\
\text { ments, } \\
\text { Sewage } \\
\text { and MSW } \\
\text { dumping }\end{array}$ & $\begin{array}{l}\text { STATE OF ENVIRONMENT } \\
\text { AND NATURAL } \\
\text { RESOURCES } \\
\text { Condition and Trends } \\
\text {-Air, Water, Land } \\
\text {-Health and living } \\
\text { conditions } \\
\text {-Flooding } \\
\text {-Water Scarcity }\end{array}$ & $\begin{array}{l}\text { Data, } \\
\text { Informati } \\
\text { on, } \\
\text { Analysis }\end{array}$ & $\begin{array}{l}\text { PUBLIC SECTOR } \\
\text {-Policy and Legislation } \\
\text {-Judiciary-directions } \\
\text { to executive } \\
\text {-Civil Society } \\
\text {-Public Interest } \\
\text { Litigation } \\
\text {-Media activism - } \\
\text { direct, hidden and } \\
\text { indirect }\end{array}$ \\
\hline
\end{tabular}

Figure 2: PSR Model explained in terms of Mumbai Metropolitan Region (MMR).

\subsection{Linear or cluster approach}

Though the geo-morphology of any two areas may largely differ a comparison between integrated coastal zone management in the Bay of Cadiz, and of the $256 \mathrm{~km}$ of the MMR coastal stretch has some lessons. Bay of Cadiz along the south Atlantic coast of Spain occupies nearly 44,000 ha of area out of which a single coastal national park of 10,500 ha is the target of management. It has provided besides the traditional salt marshes, the aquaculture activities, mollusc farming and tourism. An integrated management model of 
this kind can be an improvement on the single-track regulatory management of the coastal zone as is being presently implemented in MMR [15].

\subsection{Parameters}

For "Pressure" three parameters of urbanisation, human greed, and public sector needs will be elaborated. Their impact on the "State" through pollution, increase in encroachment on marginal lands (hill slopes, coastal lands, estuarine lands etc, and the dumping of debris and the untreated MSW and sewerage will be analysed. "State" will be examined in form of trends in the quality and quantity of air, water and land; health and living conditions; natural disasters (flooding, landslides). This information and data in the "State" will define the "Response" - to be analysed against the elements of policy and legislation; judicial intervention, civil society responses and media activism. As seen in Fig. 2, the "Response" has reverse and sometimes adverse impact on "State" which may change the strategy and content of the "Pressure".

\subsection{Analysis through parameters}

Mumbai is the financial capital of the country accounting for over $65 \%$ of the total collection of direct taxes. Two of the premier stock exchanges of the country are located here. It is a magnet for migration from the immediate hinterland and from far off places in the rest of the country. Illegal immigration from neighbouring countries particularly Bangladesh is also well documented. This has led to sharp increase in the population in the core city Mumbai in the MMR.

Table 1 highlights that since 1971 the population growth in the MMR is more pronounced in the Non-core cities. From a ratio of 1:3.32 in 1971, the population in ROMMR has grown to the ratio of 1:1.20. Since most of the fragile coastal areas covered with Mangroves are in ROMMR, therefore the impact has been felt the most in those fragile areas only. High incidence of economic activity and induced high growth in population enhanced the need for housing and civic infrastructure. Mumbai is also consequently the city with highest absolute land prices. This increased pressure on the marginal lands which became victim of human greed and human need. Builders and Developers tried to squeeze out more and more land out of the precarious eco-systems. A spate in change of the planning law followed. One section in planning legislation, which governs the density of growth was amended 27 times on "case to case" basis. Thirdly the need for civic infrastructure to enhance mobility (roads, bridges, railways) and connectivity (airport expansion and new airport) also saw more and more concessions/exemptions being given.

Table 1: Population trends in Mumbai (core city of MMR).

\begin{tabular}{|c|c|c|c|c|c|}
\hline Year & \multicolumn{2}{|c|}{ Population (million) } & \multicolumn{3}{c|}{ Average annual growth in \% } \\
\hline & Mumbai & ROMMR* & Decade & Mumbai & ROMMR* \\
\hline 1971 & 5.970 & 1.794 & & & \\
\hline 1981 & 8.243 & 2.832 & $1971-1981$ & 3.80 & 5.78 \\
\hline 1991 & 9.925 & 4.627 & $1981-1991$ & 2.04 & 6.33 \\
\hline 2001 & 11.978 & 7.387 & $1991-2001$ & 2.06 & 5.96 \\
\hline 2011 & 12.442 & 10.362 & $2001-2011$ & 3.80 & 4.02 \\
\hline
\end{tabular}

*Rest of MMR. 


\section{LAW AND COASTAL ECO-SYSTEM OF MMR}

The long journey of evolution of Environmental Law in India, as was explained earlier in this paper, can be examined in its essence by looking at following dimensions of evolution:

1. In MMR (particularly in the core city of Mumbai), the law has been focused primarily on the land component, ignoring the other two - Air and Water.

2. For Land too the prime parameter is the FSI - Floor Space Index (also called FAR Floor Area Ratio).

3. For coastal zone, one major area of evolution has been re-jigging the definition of Coastal Regulation Zone to accommodate more and more "Pressures" - of the type of human greed). This is evident in progressively reducing the width of the most sensitive coastal area lying immediately land wards of the low tide line.

4. Focus has been on protection of Mangroves - the law becoming more stringent as well more confused over a period. But with a little or no improvement in the Mangrove covered areas.

Table 2 highlights the changes in law in respect of the above dimensions.

Table 2: Evolution of Environmental Law in application to the MMR.

\begin{tabular}{|c|c|c|c|c|}
\hline \multirow[t]{2}{*}{ Period/date } & \multirow{2}{*}{$\begin{array}{l}\text { Document } \\
\text { nature }\end{array}$} & \multicolumn{2}{|l|}{ Dimension } & \multirow[t]{2}{*}{ Remarks } \\
\hline & & FSI/FAR & Extent of CRZ & \\
\hline 1987 & $\begin{array}{l}\text { Beach } \\
\text { Guidelines }\end{array}$ & Not mentioned & $\begin{array}{l}\text { Guidelines were } \\
\text { issued activity wise } \\
\text { - like } 500 \mathrm{~m} \text { for } \\
\text { thermal power } \\
\text { plants with } 5 \mathrm{~km} \text { as } \\
\text { buffer zone. This } \\
\text { was less for some } \\
\text { other categories. }\end{array}$ & $\begin{array}{l}\text { Not formal. Not } \\
\text { binding. }\end{array}$ \\
\hline $\begin{array}{l}19 \text { February } \\
1991\end{array}$ & $\begin{array}{l}\text { Notification } \\
\text { U/S } 3 \text { of the } \\
\text { EPA Act } \\
1986\end{array}$ & $\begin{array}{l}\text { FSI/FAR as per } \\
\text { the DCRs of the } \\
\text { area as on the } \\
\text { date of } \\
\text { Notification. } \\
\text { This was } 1 \text { for } \\
\text { the City of } \\
\text { Mumbai and } \\
1.33 \text { for the } \\
\text { extended } \\
\text { suburbs. }\end{array}$ & $\begin{array}{l}\text { CRZ defined as } \\
500 \mathrm{~m} \text { from HTL } \\
\text { for sea front and } \\
100 \mathrm{~m} \text { or width of } \\
\text { river, creek. Area } \\
\text { up to } 200 \mathrm{~m} \text { from } \\
\text { HTL declared as } \\
\text { NDZ in } 200-500 \mathrm{~m} \\
\text { dwelling units for } \\
\text { traditional right } \\
\text { holders allowed. } \\
\text { Also restricted } \\
\text { FSA/FAR by } \\
\text { prescribing height } \\
\text { restrictions. }\end{array}$ & $\begin{array}{l}\text { The notification } \\
\text { lacked clarity of } \\
\text { thought and vision. } \\
\text { Over enthusiastic } \\
\text { ignoring ground } \\
\text { realities. Prone to } \\
\text { multiple } \\
\text { interpretation as } \\
\text { evidenced by } \\
\text { copious litigation at } \\
\text { various levels. } \\
\text { Impractical by } \\
\text { freezing FSI to year } \\
\text { 1991 DCRs. Need } \\
\text { of coastal areas } \\
\text { within urban } \\
\text { agglomerations } \\
\text { changed over time } \\
\text { and created strong } \\
\text { Pressure. }\end{array}$ \\
\hline
\end{tabular}


Table 2: Continued.

\begin{tabular}{|c|c|c|c|c|}
\hline \multirow[t]{2}{*}{ Period/date } & \multirow{2}{*}{$\begin{array}{l}\text { Document } \\
\text { nature }\end{array}$} & \multicolumn{2}{|l|}{ Dimension } & \multirow[t]{2}{*}{ Remarks } \\
\hline & & FSI/FAR & Extent of CRZ & \\
\hline 2011 & $\begin{array}{l}\text { Notification } \\
\mathrm{u} / \mathrm{s} 3 \text { of the EP } \\
\text { Act and Rules }\end{array}$ & $\begin{array}{l}\text { FSI/FAR as per } \\
\text { the DCRs of } \\
1991 . \\
\text { Exemptions } \\
\text { allowed for } \\
\text { some } \\
\text { metropolitan } \\
\text { areas. }\end{array}$ & $\begin{array}{l}\text { CRZ as } 500 \mathrm{~m} \text { from } \\
\text { HTL. Hazard Line } \\
\text { Areas if any } \\
\text { subsumed in the } \\
\text { CRZ area. Entire } \\
\text { CRZ divided into } \\
\text { five categories and } \\
\text { norms for } \\
\text { development in } \\
\text { some categories } \\
\text { substantially diluted } \\
\text { - for some areas } \\
\text { CRZ reduced to just } \\
100 \text { m from HTL. } \\
\text { For the city of } \\
\text { Mumbai Special } \\
\text { Area status was } \\
\text { given - allowing for } \\
\text { much relaxation. } \\
\text { New parameter of } 5 \\
\text { ppm salinity } \\
\text { introduced for rivers } \\
\text { and creeks. For first } \\
\text { time Mangroves } \\
\text { areas were defined } \\
\text { as Ecologically } \\
\text { Sensitive. }\end{array}$ & $\begin{array}{l}\text { Overlapping } \\
\text { zones/sub-zones } \\
\text { without } \\
\text { clarification. Due to } \\
\text { this notification was } \\
\text { under challenge } \\
\text { form day of issue. } \\
\text { Various coastal } \\
\text { states and stake } \\
\text { holders made } \\
\text { hundreds of } \\
\text { representations. } \\
\text { Constitution of } \\
\text { another Committee. }\end{array}$ \\
\hline $\begin{array}{l}18 \text { January } \\
2019\end{array}$ & $\begin{array}{l}\text { Notification } \\
\text { under sub- } \\
\text { section (1) } \\
\text { and (2) of } \\
\text { section (3) of } \\
\text { the EP Act } \\
1986 \text {. }\end{array}$ & $\begin{array}{l}\text { FSI/FAR as per } \\
\text { the DCRs on the } \\
\text { date of } \\
\text { notification. } \\
\text { Further change } \\
\text { in FSI/FAR } \\
\text { possible by } \\
\text { following due } \\
\text { process. }\end{array}$ & $\begin{array}{l}\text { CRZ retained as } 500 \\
\mathrm{~m} \text { landward from } \\
\text { HTL. } 50 \mathrm{~m} \text { or width } \\
\text { of river/creek } \\
\text { whichever less for } \\
\text { inland. Special } \\
\text { consideration areas } \\
\text { created. Mumbai } \\
\text { City has special } \\
\text { mention. Number of } \\
\text { permissible activities } \\
\text { increased } \\
\text { substantially. Only } \\
50 \mathrm{~m} \text { as NDZ which } \\
\text { is } 200 \mathrm{~m} \text { for low } \\
\text { density development } \\
\text { areas. }\end{array}$ & $\begin{array}{l}\text { Development right } \\
\text { up to the shoreline is } \\
\text { permitted, with the } \\
\text { higher FSI/FAR. } \\
\text { Definition of the } \\
\text { "bay" (not as part of } \\
\text { this notification) } \\
\text { freed large tracts of } \\
\text { land for } \\
\text { development }\end{array}$ \\
\hline
\end{tabular}

*HTL = High Tide Line; NDZ = No Development Zone; CRZ = Coastal Regulation Zone; DCR = Development Control Regulations; EP Act = Environment Protection Act 1986. 


\section{CONCLUSIONS}

The case study highlights the Pressure element in the model driving the changes in behavior and action of the stake holders. Rapid urbanisation due to migration from the hinterland to the case study area has increased the level of economic activity and demand for housing and infrastructure. To accommodate this the periphery of the core city grew at more than double rate compared to the core city. This brought under pressure the marginal lands coastal stretches included. High property prices led to even more increased pressure to ease the restrictions on development which progressively happened from 1991 to 2019. Coastal areas in the MMR are impacted due to large scale debris-dumping, sometimes in a planned way to reclaim the land - an element of human greed. Other impacts are due to the human need of housing and infrastructure. Very ambitious legislation is enacted which over time is diluted or altogether replaced with a milder legislation. The dynamics, fluidity and two-way action of the PSR model is in full play in MMR. As also noted by other authors on the subject, the frequent changes in law are seeded right from the day of its enunciation. Highly ambitious initial law ignores the ground realities of the need for steady growth, economic impact of the law on property owners. Though the environment vs. development debate is endless the need to strike a balance has been highlighted at many international fora notable the Rio Declaration of 2012.

\section{REFERENCES}

[1] Government of India, The Environment Protection Act, 1986.

[2] Strack, M., Sustainable coastal development: Protect or retreat. WIT Transactions on The Built Environment, vol. 170, WIT Press: Southampton and Boston, 2017.

[3] Ministry of Environment and Forest, Government of India, Notifications (1991, 2011, 2019) under section 3 of the Environment Protection Act.

[4] High Court of Judicature, Bombay, Judgement in PIL 218 of 2013 and 58 of 2018, Navi Mumbai Environmental Preservation Society vs. Ministry of Environment and Others, 2018.

[5] Supreme Court of India, Judgement in Intellectuals Forum vs. State of Andhra Pradesh and Fomento Resorts and Hotels Ltd vs. Minguel Martins and Others, 2009.

[6] Rio Declaration on Environment and Development, 1992.

[7] Supreme Court of India.

[8] OECD Environment Directorate, Using the Pressure-State-Response Model to develop indicators of Sustainability, OECD Framework for Environmental Indicators.

[9] Kristensen, P., The DPSIR framework. Presented at The Workshop on Comprehensive/Detailed Assessment of the Vulnerability of Water Resources, UNEP Headquarters, Nairobi, Kenya, 2004.

[10] The Energy and Resources Institute, Western Region Centre, Environmental status report of Mumbai Metropolitan Region (MMR), 2015.

[11] Mumbai Metropolitan Development Authority, Regional Development Plan.

[12] Gill, G.S. \& Shinde, K., Strategy for creation of infrastructure and launch of water transport in Mumbai Metropolitan Region and surrounding areas, 2016.

[13] HCP Design and Project Mgt. Pvt. Ltd., Inventory for Mumbai Metropolitan Region Environment Improvement Society, 2012.

[14] Murthy, R.C, et al., Integrated coastal management of Mumbai metropolitan region. Ocean and Coastal Management, 44, 2001.

[15] de Andres, M. \& Barragan, J.M., Urban development and integrated coastal zone management in the Bay of Cadiz. WIT Transactions on the Built Environment, vol. 170, WIT Press: Southampton and Boston, 2017. 